\title{
Regulation of angiopoietin-like protein 4/fasting-induced adipose factor (Angptl4/FIAF) expression in mouse white adipose tissue and 3T3-L1 adipocytes
}

\author{
Sarah Dutton and Paul Trayhurn* \\ Obesity Biology Unit (Liverpool Obesity Research Network), School of Clinical Sciences, University of Liverpool, Duncan \\ Building, Liverpool L69 3GA, UK
}

(Received 19 July 2007 - Accepted 28 September 2007 - First published online 17 December 2007)

Angiopoietin-like protein 4 (Angpt14)/FIAF (fasting-induced adipose factor) was first identified as a target for PPAR and to be strongly induced in white adipose tissue (WAT) by fasting. Here we have examined the regulation of the expression and release of this adipokine in mouse WAT and in 3T3-L1 adipocytes. Angpt14/FIAF expression was measured by RT-PCR and real-time PCR; plasma Angpt14/FIAF and release of the protein in cell culture was determined by western blotting. The Angpt14/FIAF gene was expressed in each of the major WAT depots of mice, the mRNA level in WAT being similar to the liver and much higher ( $>50$-fold) than skeletal muscle. Fasting mice $(18 \mathrm{~h})$ resulted in a substantial increase in Angpt14/FIAF mRNA in liver and muscle (9.5- and 21-fold, respectively); however, there was no effect of fasting on Angptl4/FIAF mRNA in WAT and the plasma level of Angpt14/FIAF was unchanged. The Angpt14/FIAF gene was expressed in 3T3-L1 adipocytes before and after differentiation, the level increasing post-differentiation; Angptl4/FIAF was released into the culture medium. Insulin, leptin, dexamethasone, noradrenaline, TNF $\alpha$ and several IL (IL-1 $\beta$, IL-6, IL-10, IL-18) had little effect on Angpt14/FIAF mRNA levels in 3T3-L1 adipocytes. However, a major stimulation of Angptl4/FIAF expression was observed with rosiglitazone and the inflammatory prostaglandins $\mathrm{PGD}_{2}$ and PGJ Pngpt14/FIAF does $_{2}$ not act as an adipose tissue signal of nutritional status, but is markedly induced by fasting in liver and skeletal muscle.

Adipose tissue: Adipokines: Angiopoietin-like protein 4: Fasting

Since the discovery of the lipostatic hormone leptin in $1994^{(1)}$, a wide diversity of protein signals and factors, known as adipokines, have been found to be secreted from white adipose tissue $(\text { WAT })^{(2-4)}$. This has greatly expanded the classical view of the tissue as a simple lipid storage organ to encompass a major secretory role. One intriguing protein produced by WAT is angiopoietin-like factor 4 (Angplt4), a secreted glycoprotein ${ }^{(5)}$. Angplt4 was first identified as a target of the nuclear receptor family PPAR ${ }^{(6,7)}$, and although expression has been detected in a number of tissues, it is notably high in WAT, brown adipose tissue and the placenta $^{(5-8)}$. Sequence analysis has shown that it is closely related to Angptl3, a protein exclusively expressed within the liver ${ }^{(9)}$, with both proteins containing a coiled-coil domain near their $\mathrm{N}$-terminus and a fibrinogenlike domain near the $\mathrm{C}$-terminus ${ }^{(10)}$.

Angplt4 was first identified in adipose tissue as a fasting-induced adipose factor (FIAF), that was substantially up-regulated during fasting ${ }^{(6)}$, raising the possibility that it could play a major role in signalling nutritional deprivation. Subsequent studies have not only connected this adipokine (which we refer to as Angptl4/FIAF) with a putative role in energy regulation ${ }^{(6,11-14)}$, but also in angiogenesis ${ }^{(15,16)}$. Administration of Angptl4/FIAF by intravenous injection or by adenoviral-mediated over-expression dramatically raises plasma TAG levels, an effect mediated by reduced VLDL clearance due to the potent inhibition of lipoprotein lipase (LPL) activity ${ }^{(11,12,14,16)}$. With respect to angiogenesis, it was found that Angptl4/FIAF stimulates nodule expression when grafted on to chick chorioallantoic membranes ${ }^{(15)}$ and also to stimulate in vitro tube formation of pulmonary artery endothelial cells and angiogenesis in mice ${ }^{(17)}$. Angptl4/FIAF has also been shown to be up-regulated in conditions that promote angiogenesis ${ }^{(16,18)}$, being increased in hypoxia ${ }^{(15,19)}$ and in some cancer cell lines ${ }^{8,15)}$. Although identified as a target for PPAR, changes in Angpt14/FIAF expression are also mediated through other pathways; HIF- $1 \alpha$ and the PPAR agonist Wy14643 act synergistically in neonatal rat cardiomyocytes ${ }^{(19)}$ and regulation by PPAR- $\alpha$ in the liver of mice has been shown to be lost with fasting ${ }^{(6)}$.

Despite the strong expression of Angpt14/FIAF in WAT, together with the high LPL activity in the tissue, little is known of the regulation of this adipokine. Nor is it clear whether there are major differences between the various fat depots, particularly in response to fasting; for a number of adipokines, distinct depot-dependent expression profiles are evident $^{(20,21)}$. In the present study, we show that there is strong Angptl4/FIAF expression in each WAT depot, but surprisingly fasting did not stimulate expression in any depot examined, despite a substantial fasting-induced increase in expression 
in liver and skeletal muscle. 3T3-L1 cells were then used to gain insight into the key regulators of a Angptl4/FIAF expression in adipocytes. The cell culture studies indicate that Angptl4/FIAF expression in adipocytes is strongly stimulated by the pro-inflammatory $\mathrm{PGD}_{2}$ as well as by the PPAR $\gamma$ agonist, rosiglitazone.

\section{Material and methods}

Animals

Adult male CD-1 mice, aged 9 weeks, were obtained from Charles River (UK). The mice were individually housed in a temperature-controlled room $\left(21^{\circ} \mathrm{C}\right)$ with a $12 \mathrm{~h}-12 \mathrm{~h}$ lightdark cycle (lights on at 07.00 hours). The animals were fed a commercial rodent diet (CRM Diet, Labsure, UK) containing $19.2 \%$ protein and $4.3 \%$ lipid (w/w). Both food and water were available ad libitum. Fasted mice were deprived of food for $18 \mathrm{~h}$, starting at 17.00 hours. Both fed and fasted animals were killed by cervical dislocation, and the following tissues were rapidly removed and frozen in liquid nitrogen: liver, muscle and three WAT depots (subcutaneous, epididymal and perirenal). All tissues were stored at $-80^{\circ} \mathrm{C}$ until analysis.

\section{Cell culture}

3T3-L1 cells (American Type Culture Collection, USA) were maintained and cultured as previously ${ }^{(22)}$. In brief, cells were cultured at $37^{\circ} \mathrm{C}$ in a humidified atmosphere of $5 \% \mathrm{CO}_{2}-95 \%$ air. Preadipocytes were maintained in culture medium containing Dulbecco's modified Eagle's medium (Invitrogen, UK) supplemented with $10 \%$ (v/v) fetal calf serum (Sigma, UK). Differentiation was initiated $24 \mathrm{~h}$ after confluence by incubation for $2 \mathrm{~d}$ in culture medium containing $0 \cdot 25 \mu \mathrm{M}$-dexamethasone, $0.5 \mathrm{~mm}-3$-isobutyl-1-methylxanthine and $5 \mathrm{mg} / \mu \mathrm{l}$ insulin (Sigma). Subsequently, the cells were maintained in feeding medium consisting of culture medium (Dulbecco's modified Eagle's medium plus fetal calf serum) containing $5 \mu \mathrm{g} / \mathrm{ml}$ insulin for up to $20 \mathrm{~d}$.

To study the time course of the expression of Angptl4/ FIAF, cells were collected every $1-2 \mathrm{~d}$. The effects of agents were tested on cells that were $10-12 \mathrm{~d}$ after the induction of differentiation. Before treatment $(24 \mathrm{~h})$ the media was changed and the cells were pre-incubated for $24 \mathrm{~h}$ in feeding media (Dulbecco's modified Eagle's medium plus fetal calf serum), insulin-free feeding medium (for the study on the effects of insulin) or fetal calf serum-free feeding medium (treatment medium for rosiglitazone, cytokines, PG). Cells were then treated with medium containing each of the specific agents to be tested: rosiglitazone (low dose $0 \cdot 1 \mu \mathrm{M}$, high dose $1 \mu \mathrm{M}$; GlaxoSmithKline, UK), insulin $(1 \mu \mathrm{M}, 10 \mu \mathrm{M})$, dexamethasone $(2 \mathrm{nM}, 20 \mathrm{nM})$, leptin $(0 \cdot 1 \mu \mathrm{M}, 2 \mu \mathrm{M})$, IL-6 $(1 \mathrm{ng} /$ $\mathrm{ml}, 25 \mathrm{ng} / \mathrm{ml})$ (Sigma), noradrenaline $(0 \cdot 1 \mu \mathrm{M}, 1 \mu \mathrm{M}$; Fluka, Switzerland), IL-1 $\beta \quad(5 \mathrm{ng} / \mathrm{ml}, 20 \mathrm{ng} / \mathrm{ml}), \quad$ IL-10 $\quad(5 \mathrm{ng} / \mathrm{ml}$, $20 \mathrm{ng} / \mathrm{ml}$ ) (PeproTech EC, UK), IL-18 (100 ng/ml, $500 \mathrm{ng} /$ $\mathrm{ml}$; R\&D Systems, USA), $\mathrm{PGE}_{2}, \mathrm{PGF}_{2} \alpha$ and $\mathrm{PGD}_{2}(50 \mu \mathrm{M}$ and $100 \mu \mathrm{M}) \mathrm{PGI}_{2}(50 \mu \mathrm{M}$ and $150 \mu \mathrm{M})$ (Alexis Chemicals, UK). The control cells underwent the same procedure as treated cells, but no agent was added. Cells were collected in $700 \mu \mathrm{l}$ Trizol (Invitrogen) at $24 \mathrm{~h}$ after the addition of the various agents. Medium was also collected and centrifuged at $1000 \mathrm{rpm}$ for $10 \mathrm{~min}$, the supernatant being stored together with the cells at $-80^{\circ} \mathrm{C}$ until use.

The dose response of the effects of $\mathrm{PGD}_{2}$ and its derivatives on Angpt14/FIAF expression were studied by treating cells with different concentrations of PG for $24 \mathrm{~h}$.

\section{$R T-P C R$}

Total RNA was extracted with Trizol (Invitrogen) and any genomic DNA contamination was removed using a DNAfree kit (Ambion, UK), in accordance with the manufacturer's instructions. The concentration of each sample was determined from the absorbance at $260 \mathrm{~nm}$.

Total RNA $(1 \mu \mathrm{g})$ was reverse-transcribed to cDNA in a $20 \mu \mathrm{l}$ reaction volume with anchored oligo(dt) primer using a ReverseiT $^{\mathrm{TM}} 1$ st Strand Synthesis Kit (Abgene, UK). Each cDNA sample $(1 \mu \mathrm{l})$ was then amplified in a PCR mixture containing $0.02 \mathrm{~mm}$ of each primer and $1 \cdot 1 \times$ Reddy Mix PCR Master Mix (Abgene) in a final volume of $25 \mu$ l. Mouse $\beta$-actin was used as a housekeeping gene. The primer pairs used and the PCR conditions are as follows. Mouse Angptl4/FIAF (531 bp product): $5^{\prime}-3^{\prime}$ TTC CAA CGC CAC CCA CTT ACA (sense); $5^{\prime}-3^{\prime}$ ACCAAACCACCAGCCACCAGA (anti-sense); annealing temperature $58^{\circ} \mathrm{C}$; twenty-eight cycles. Mouse $\beta$-actin ( $463 \mathrm{bp}$ product): $5^{\prime}$ $3^{\prime}$ TGCTGTCCCTGTATGCCTCT (sense); 5'-3' AGGTCTTTACGGATGTCAACG (anti-sense); annealing temperature $60^{\circ} \mathrm{C}$; twenty-four cycles. Mouse leptin (394 bp product): $5^{\prime}-3^{\prime}$ CTGTCTTATGTTCAAGCAGTGCCTAT (sense); 5'-3' AAGCCACCACCTCTGTGGAGTA (anti-sense); annealing temperature $62^{\circ} \mathrm{C}$; thirty-five cycles. Mouse adiponectin $(430 \mathrm{bp}$ product): $5^{\prime}-3^{\prime}$ TTAATCCTGCCCAGTCATGCCG (sense); 5'-3' AGAACTTGCCAGTGCTGCCGTC (anti-sense); annealing temperature $62^{\circ} \mathrm{C}$; thirty cycles.

PCR was performed on a thermal cycler (Hybaid, UK) with an initial denaturation at $94^{\circ} \mathrm{C}$ for 2 min followed by cycles consisting of denaturation at $94^{\circ} \mathrm{C}$ for $20 \mathrm{~s}$, annealing at the specified temperature for $30 \mathrm{~s}$ and extension at $72^{\circ} \mathrm{C}$ for $40 \mathrm{~s}$; the final step was an extension at $72^{\circ} \mathrm{C}$ for $5 \mathrm{~min}$. PCR products were separated on a $1 \%$ agarose gel stained with ethidium bromide. The PCR products were sequenced commercially to confirm their identity (MWG Biotech, Germany).

\section{Real-time PCR}

Relative Angptl4/FIAF expression was quantified using the $2^{-\Delta \Delta C t}$ method with either an ABI Prism 7700 Sequence detector (Applied Biosystems, USA) or a Stratagene MX3005P instrument (Stratagene, The Netherlands). All sample values were normalised against $\beta$-actin values and the results expressed as fold changes of threshold cycle $(\mathrm{Ct})$ value relative to controls. Primer and probe sequences were designed using Primer Express software (Applied Biosystems). Primers and probes were synthesised commercially (Eurogentec, UK). Sequences were as follows. Mouse Angptl4/ FIAF (110 bp product): 5'-3' GGGACCTTAACTGTGCCAAGAG (sense); 5'-3' GGAAGTATTGTCCATTGAGATTGG A (anti-sense), $5^{\prime}-3^{\prime}$ FAM-CTCTCTGGTGGC TGGTGGTTTGGTAC-TAMRA (probe). Mouse $\beta$-actin (71 bp product): $5^{\prime}-3^{\prime}$ ACGGCCAGGTCATCACTATTG (sense), 5'-3' CAA GAAGGAAGGCTGGAAAAG (anti-sense), $5^{\prime}-3^{\prime}$ FAM-ACGAGCGGTTCCGATGCCCTG-TAMRA (probe). 
Amplification was performed in a ninety-six-well plate using a mix made from a qPCR core Kit (Eurogentec), with $900 \mathrm{~nm}$ forward and $900 \mathrm{~nm}$ reverse primers, $200 \mathrm{~nm}$ (225 nM in the case of the $\beta$-actin) probe and $1 \mu \mathrm{l}$ cDNA to a final volume of $25 \mu \mathrm{l}$. For analysis on the Stratagene instrument, the same concentrations were used, but only $0.5 \mu \mathrm{l}$ cDNA was added to a final volume of $12.5 \mu \mathrm{l}$. Each sample was run at least in duplicate for both Angptl4/FIAF and $\beta$-actin. Amplifications were performed commencing with a 2 min activation stage at $50^{\circ} \mathrm{C}$, denaturation at $95^{\circ} \mathrm{C}$ for $10 \mathrm{~min}$ followed by forty cycles of denaturation at $95^{\circ} \mathrm{C}$ for $15 \mathrm{~s}$ and combined annealing and extension at $60^{\circ} \mathrm{C}$ for $1 \mathrm{~min}$. Data were recorded and analysed with Sequence Detector software (Applied Biosystems or Stratagene).

\section{Western blotting}

To collect protein from culture media, samples of medium were incubated with TCA to a final concentration of $12.5 \%$ for $3 \mathrm{~h}$ on ice and then centrifuged at $12000 \mathrm{~g}$ for $30 \mathrm{~min}$ at $4^{\circ} \mathrm{C}$. The protein pellet was dissolved in $1 \%$ SDS. The protein concentration was determined using the bicinchoninic acid $\operatorname{assay}^{(23)}$.

A polyclonal antibody was raised, using Eurogentec's Double $\mathrm{X}$ program, against the epitopes KGKDAPFKDSEDRVP and QSWEAYKDGFGDPQG present in the $\mathrm{N}$ - and C-terminal regions of mouse Angpt14/FIAF protein, respectively. Samples of protein were separated by SDS-PAGE on $10 \%$ polyacrylamide gels. The proteins were then transferred to nitrocellulose membranes (Hybond C; Amersham Pharmacia, UK) and immunoblotting was performed overnight at $4{ }^{\circ} \mathrm{C}$. A rabbit polyclonal antibody to mouse Angpt14/FIAF was generated commercially (Eurogentec) and employed at a 1:500 dilution in Tris-buffered saline (pH 7.4) containing 0.1\% Tween and $7 \%$ dried milk. Blots were then incubated for $1 \mathrm{~h}$ at room temperature with a sheep anti-rabbit secondary antibody conjugated to horseradish peroxidase (Santa Cruz Biotechnology, USA) at a 1:1000 dilution. Signals were detected with the enhanced chemiluminescence system (Amersham Pharmacia).

\section{Statistical analysis}

The statistical significance of differences between tissues or groups of treated cells was assessed by Student's unpaired $t$ test; differences were considered to be significant when $P<0 \cdot 05$.

\section{Results}

Expression of angiopoietin-like protein 4/fasting-induced adipose factor in different adipose tissue depots

In the initial studies, the expression of Angptl4/FIAF was examined in different WAT depots by RT-PCR. A single band of approximately 531 bp was detected (Fig. 1 (a)) and the identity of this band as mouse Angptl4/FIAF was confirmed by sequencing. Angptl4/FIAF was expressed in each of the five major WAT depots examined (subcutaneous, epididymal, omental, mesenteric and perirenal), as well as in interscapular brown adipose tissue. There was also a strong signal in the liver, and faint bands were additionally observed in the (a)
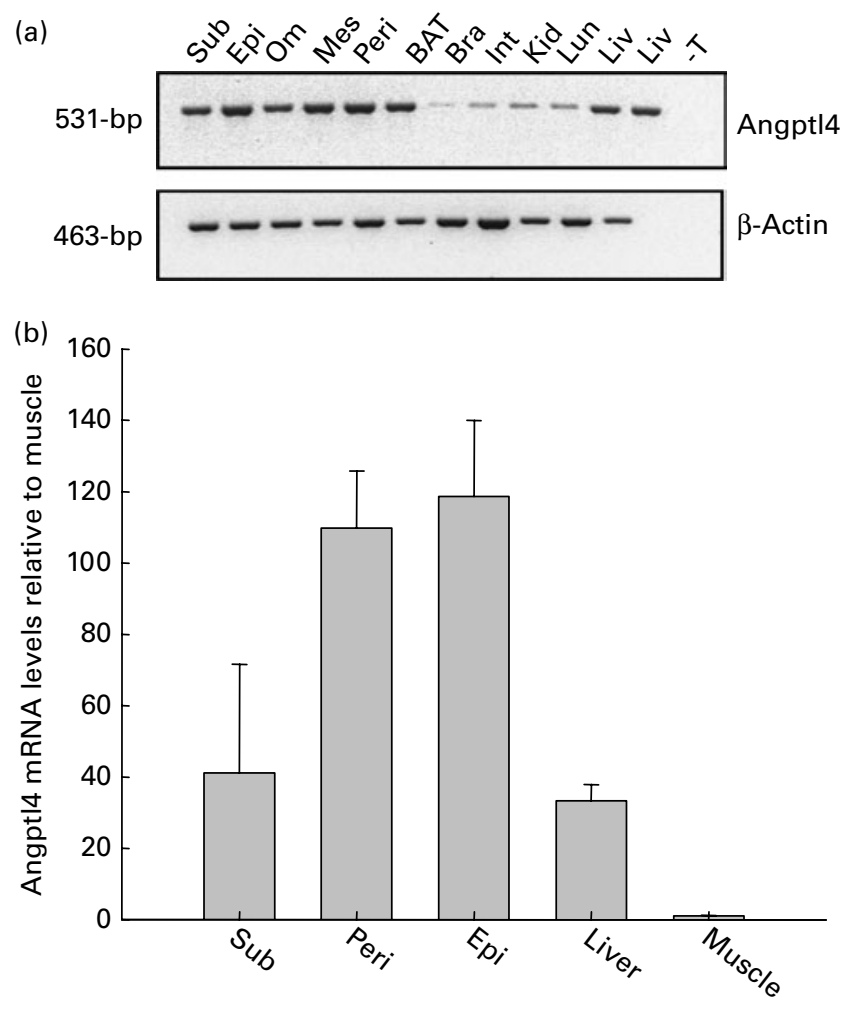

(c)
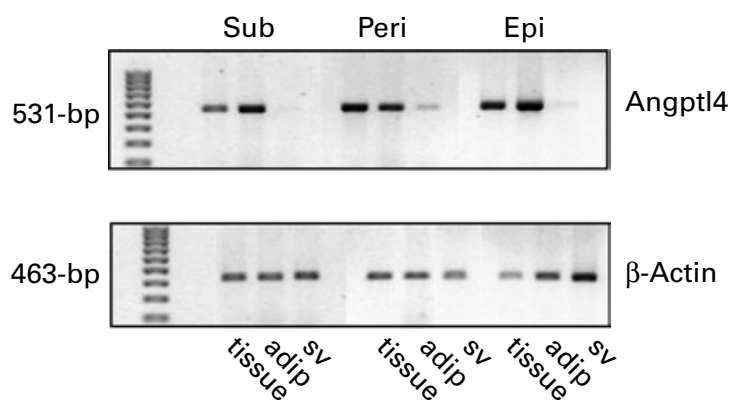

Fig. 1. Angiopoietin-like protein 4/fasting-induced adipose factor (Angpt/4/FIAF) expression in mouse tissues. (a) Expression of Angplt4 in a range of mouse tissues, including five white adipose tissue depots, by RTPCR. (b) Quantitation of Angpt/4/FIAF mRNA levels by real-time PCR in mouse tissues. (c) Angptl4/FIAF expression by RT-PCR in mature adipocytes (adip) and stromal vascular (sv) cells isolated from subcutaneous (Sub), perirenal (Peri) and epididymal (Epi) depots by collagenase digestion. BAT, interscapular brown adipose tissue; Bra, brain; Int, Intestine; Kid, kidney; Liv, liver; Lun, lung; Mes, mesenteric; Om, omental; T, no template control.

brain, small intestine, kidney and lung, tissues in which Angptl4/FIAF is known to be also expressed ${ }^{(6,7,24,25)}$.

Real-time PCR was used to quantitate the relative levels of Angptl4/FIAF mRNA in the three major WAT depots. There was no significant difference in expression between the subcutaneous, epididymal and perirenal depots, although subcutaneous expression was lower (Fig. 1 (b)). Angpt14/FIAF mRNA level was, however, significantly higher in both the epididymal and perirenal WAT than in the liver. The level of Angptl4/FIAF mRNA in skeletal muscle was considerably lower than in either the liver or the WAT depots, being 50-fold lower than in subcutaneous WAT (Fig. 1 (b)).

Adipose tissue is heterogeneous at the cellular level. To determine whether Angptl4/FIAF is expressed solely within 
adipocytes, or within the stromal vascular fraction as well, cDNA was obtained from samples of subcutaneous, epididymal and perirenal WAT which had undergone digestion with collagenase and separated into the two fractions ${ }^{(26)}$. RT-PCR revealed that Angptl4/FIAF mRNA was present almost exclusively in the adipocytes themselves; only with the perirenal depot was a faint band observed in the stromal vascular fraction (Fig. 1 (c)).

Effect of fasting on the expression of angiopoietin-like protein 4/fasting-induced adipose factor in different tissues

Angpt14/FIAF was originally identified as a gene whose expression was markedly increased in WAT by fasting ${ }^{(6)}$. The depot used was not defined in the original study, and to investigate whether fasting may affect each WAT depot, real-time PCR was used to quantify the changes in expression in tissues of mice following a fast $(18 \mathrm{~h})$. Control mice were fed without restriction. The body weight of the fasted mice was on average $23 \%$ lighter than their fed counterparts. Surprisingly, there was no significant increase in Angptl4/FIAF mRNA level in any of the WAT depots tested (Fig. 2 (a)). In marked contrast, there was a substantial increase in Angptl4/FIAF expression in the liver and skeletal muscle, the mRNA level increasing 9.5- and 21-fold in the two tissues, respectively (Fig. 2 (a)).

To investigate whether the circulating level of Angptl4/FIAF was altered in response to fasting, western blotting was performed on plasma from fed and fasted mice. A strong band of approximately $64 \mathrm{kDa}$, consistent with Angptl4/FIAF, was detected in each lane (Fig. 2 (b)); this band was not detected in blots that had been incubated with either pre-immune serum or secondary antibody alone. Preincubation of the antibody with the peptides against which it was raised also considerably reduced the intensity of the band, providing further evidence that the band detected was indeed Angpt14/FIAF. Densitometric measurements of the band showed no difference in the plasma level between fed and fasted mice (Fig. 2 (b)).

\section{Angiopoietin-like protein 4/fasting-induced adipose factor} expression in 3T3-L1 adipocytes

In the next set of experiments the murine 3T3-L1 cell line was used to directly examine the regulation of Angptl4/FIAF expression in adipocytes in vitro. First, the expression of Angpt14/FIAF was determined throughout the maturation of 3T3-L1 cells into mature adipocytes using RT-PCR and compared to that of adiponectin and leptin, two markers of adipocyte differentiation. Angptl4/FIAF mRNA was detected both before and after the induction of differentiation, whereas adiponectin and leptin mRNA were only detected from day 2 post-induction (Fig. 3 (a)).

Real-time PCR was then used to quantify Angptl4/FIAF mRNA levels in 3T3-L1 adipocytes (Fig. 3 (b)). Angptl4/ FIAF expression was low pre-differentiation, and apart from day 2 where a peak in expression was observed (which may be a specific response to components of the induction cocktail), the mRNA level increased gradually after differentiation, being 6 -fold greater by day 8 . Although there was some variation between days 8 and 18, Angptl4/FIAF expression remained relatively constant and did not change greatly until day 20 .

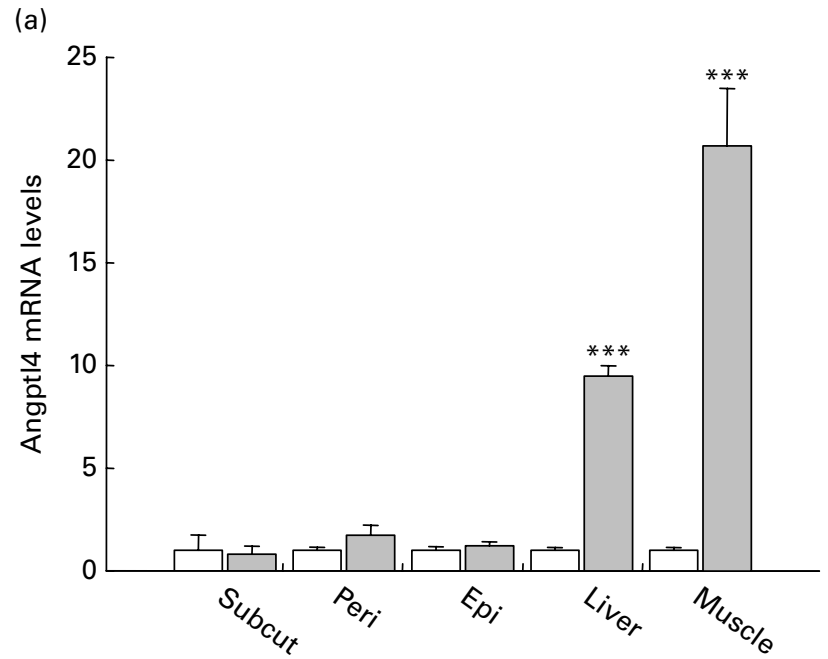

(b)
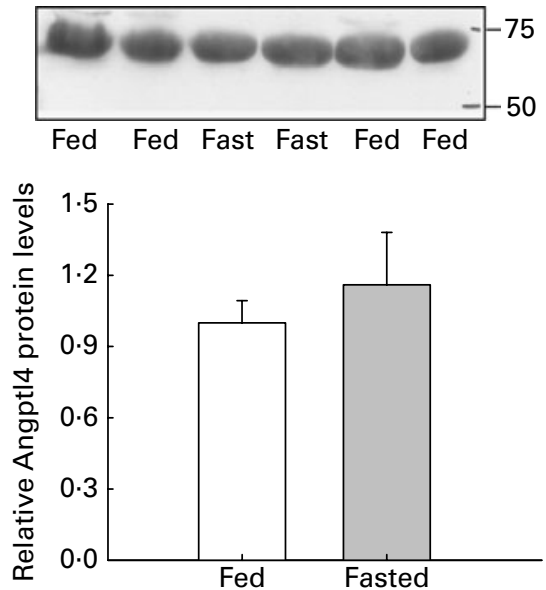

Fig. 2. Effect of an $18 \mathrm{~h}$ fast on angiopoietin-like protein 4 (Angplt4) mRNA levels in epididymal (Epi), perirenal (Peri) and subcutaneous (Subcut) white adipose tissue, liver and muscle of CD1 mice. (a) Relative Angplt4 mRNA levels in the Subcut, Peri and Epi depots, and in the liver and skeletal muscle from fed $(\square)$ and fasted $(\square)$ mice measured by real-time PCR and expressed relative to the corresponding tissue from fed mice. (b) Angpt/4/fastinginduced adipose factor (FIAF) abundance was measured in the plasma of fed and fasted mice by western blotting (representative blot); quantified bands are presented in the accompanying bar graph. Values are means with their standard errors depicted by vertical bars $(n 7-10)$. Mean values were significantly different from those of the control group: ${ }^{\star \star \star} P<0.001$.

The medium was subsequently examined by western blotting to determine whether Angptl4/FIAF protein was secreted from the 3T3-L1 adipocytes. The pattern of Angptl4/FIAF in the medium was generally similar to the pattern of gene expression in the cells: Angpt14/FIAF could be detected in the medium prior to differentiation with levels increasing post-differentiation (Fig. 4). The level of Angpt14/FIAF in the medium was highest at day 18, at which point it had increased nearly 6-fold over the pre-induction level.

\section{Regulation of angiopoietin-like protein 4/fasting-induced} adipose factor gene expression in 3T3-L1 cells

Angptl4/FIAF is thought to be involved in energy regulation and is an inhibitor of $\operatorname{LPL}^{(10,11,14)}$. To determine whether Angpt14/FIAF is regulated by factors that are involved in 
(a)

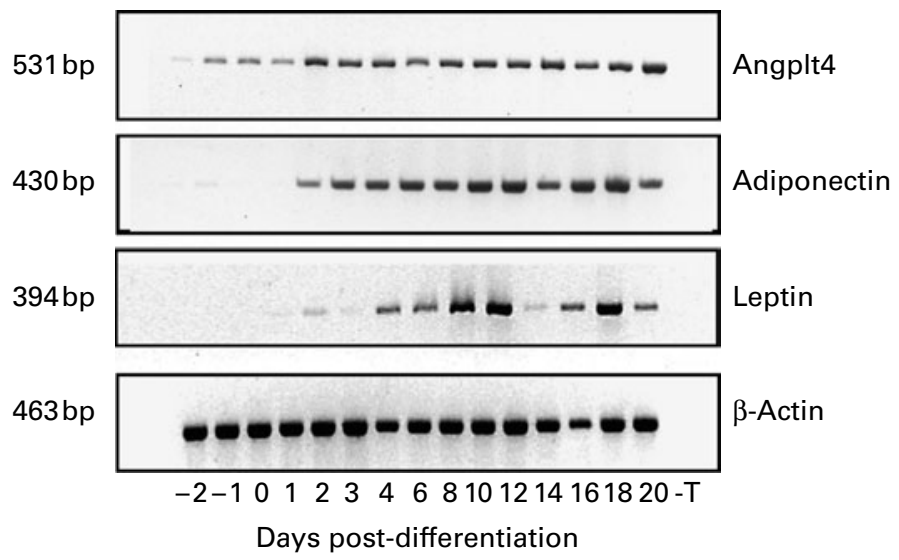

(b)

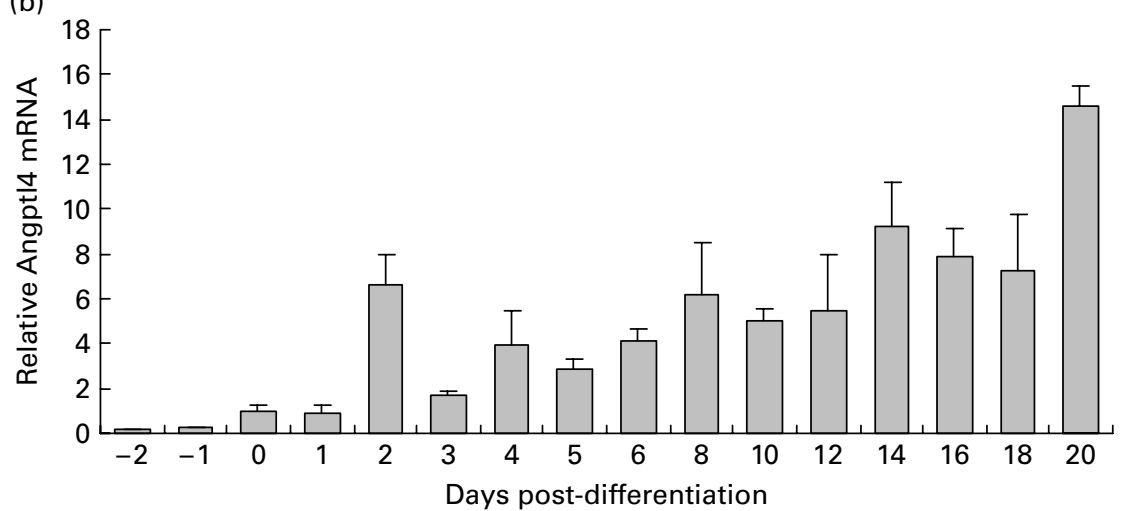

Fig. 3. Angiopoietin-like protein 4/fasting-induced adipose factor (Angpt/4/FIAF) gene expression during the differentiation and development of 3T3-L1 cells into adipocytes. (a) Angpt/4/FIAF, adiponectin and leptin mRNA expression detected by RT-PCR in 3T3-L1 cells; differentiation was induced at day 0. (b) Relative Angpt//FIAF mRNA levels measured by real-time PCR in 3T3-L1 cells. Values are means with their standard errors depicted by vertical bars $(n 6)$.
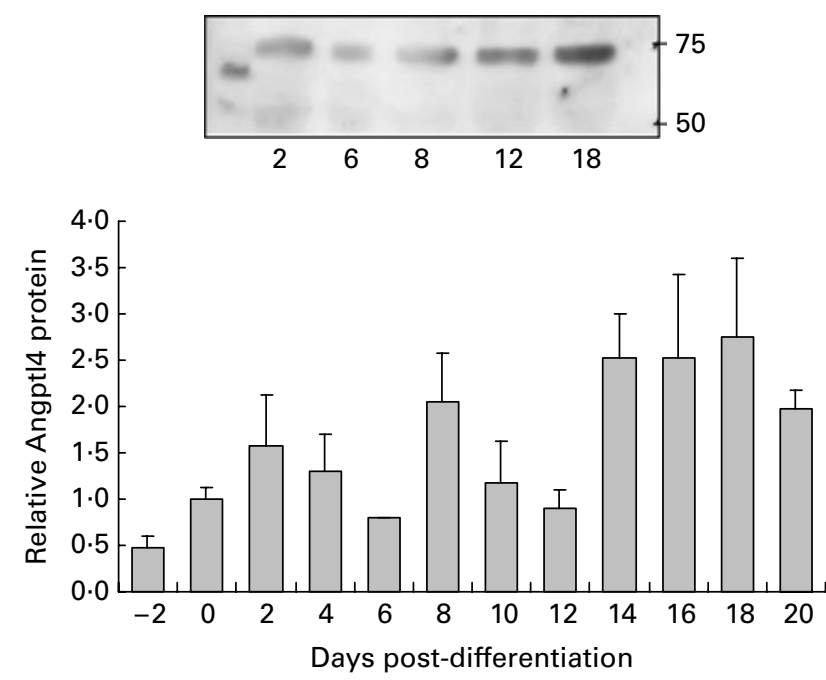

Fig. 4. Angiopoietin-like protein $4 /$ fasting-induced adipose factor (Angpt/4/FIAF) protein secretion during differentiation and development of 3T3-L1 cells into adipocytes. Angpt/4/FIAF abundance was measured in the media of cells at $2 \mathrm{~d}$ intervals throughout by western blotting. A representative blot is shown and quantification of the bands is shown in the accompanying bar graph. Values are means with their standard errors depicted by vertical bars $(n 3)$. energy homeostasis, 3T3-L1 cells were treated with insulin, leptin, the synthetic glucocorticoid dexamethasone and noradrenaline for $24 \mathrm{~h}$. A set of cells was also treated with rosiglitazone given the reports that Angptl4/FIAF is induced by PPAR $\gamma$ agonists. Neither leptin nor noradrenaline had any effect on Angptl4/FIAF mRNA levels (Fig. 5 (a)). Treatment with dexamethasone led to a small decrease in mRNA level, to approximately half the control value, while insulin resulted in a modest 1.5-fold increase at both doses; however, this increase was only statistically significant at the higher dose (Fig. 5 (a)). In marked contrast, treatment with rosiglitazone strongly stimulated Angptl4/FIAF expression, the mRNA level increasing more than 8.5-fold at both doses (Fig. 5 (a)).

The medium was examined to determine whether the increase in Angptl4/FIAF mRNA level in the cells induced by rosiglitazone was paralleled by a rise in the amount of the encoded protein released. The identification of the bands detected as Angpt14/FIAF was confirmed by using a second antibody raised in chickens (Aves-lab) against the peptide sequence QYFHSIPRQRQERKK located near the C-terminal of mouse Angptl4. Quantification of the major bands showed that treatment with rosiglitazone for $24 \mathrm{~h}$ did not alter the extent of protein secretion into the medium (Fig. 5 (b)).

Recently, it has been shown that Angpt14/FIAF expression is increased in collagen-induced arthritis, an experimental model of inflammatory arthritis ${ }^{(16)}$. To test whether Angptl4/ FIAF expression is mediated by inflammatory agents, the 

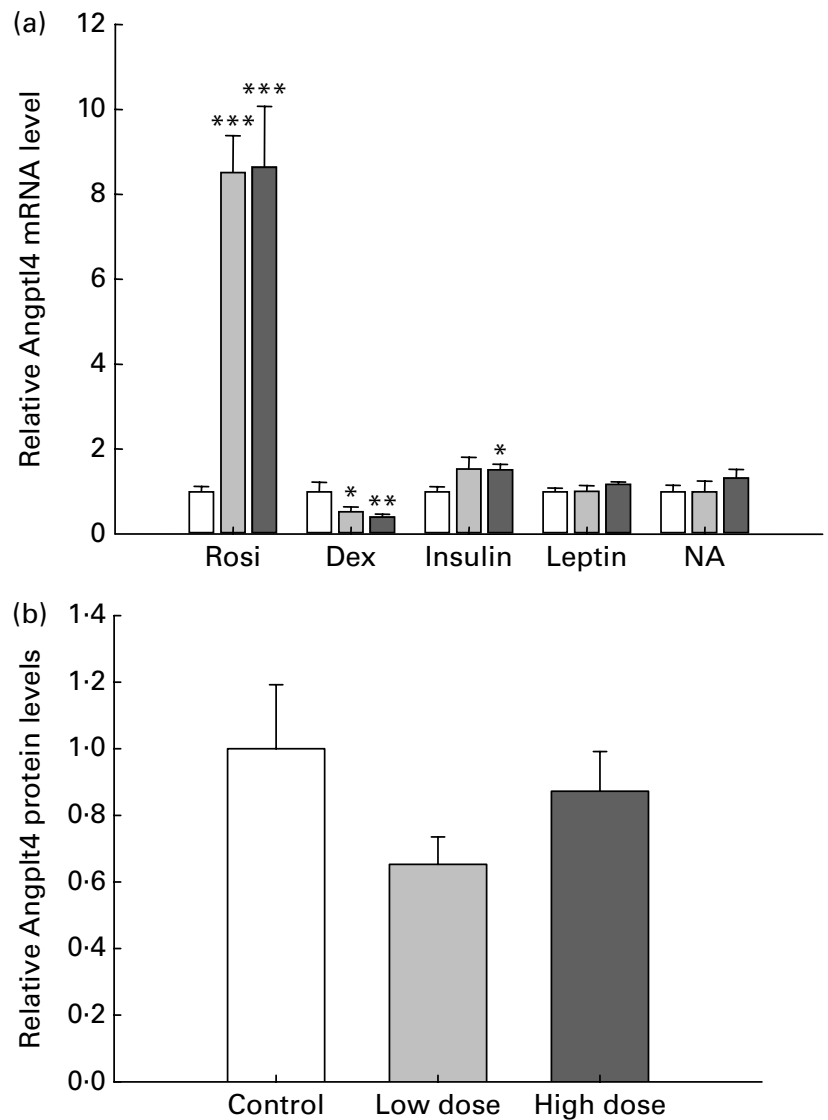

Fig. 5. Effect of rosiglitazone (Rosi), dexamethasone (Dex), insulin, leptin and noradrenaline (NA) on angiopoietin-like protein 4/fasting-induced adipose factor (Angpt/4/FIAF) levels in 3T3-L1 adipocytes. Cells were treated at day 10 after induction of differentiation and incubated for $24 \mathrm{~h}$ in medium to which different amounts of each agent were added ( $\square$, low dose; $\square$, high dose); control cells ( $\square$ ) received no addition. (a) Rosi low dose $0.1 \mu \mathrm{M}$; Rosi high dose $1 \mu \mathrm{M}$; Dex low dose $2 \mathrm{~nm}$, Dex high dose, $20 \mathrm{~nm}$; Insulin low dose $1 \mu \mathrm{M}$; insulin high dose $10 \mu \mathrm{M}$; leptin low dose $0.1 \mu \mathrm{M}$, leptin high dose $2 \mu \mathrm{M}$; NA low dose $0.1 \mu \mathrm{M}$, NA high dose $1 \mu \mathrm{M}$. Values for Angpt/4/FIAF mRNA levels, measured by real-time PCR, are expressed relative to their respective controls. (b) Angpt|4/FIAF abundance in the media of cells treated with rosiglitazone was measured by western blotting. Total protein from duplicate samples were pooled and loaded on to each lane. Quantified bands are presented in the accompanying bar graph. Values are means with their standard errors depicted by vertical bars $(n 5-6)$. Mean values were significantly different from those of the control group: ${ }^{\star} P<0.05$, ${ }^{\star \star} P<0.01,{ }^{\star \star \star} P<0.001$.

effects of TNF- $\alpha$, IL-1 $\beta$, IL-6, IL-10 and IL-18, as well as $\mathrm{PGE}_{2}, \mathrm{PGF}_{2 \alpha}, \mathrm{PGI}_{2}$ and $\mathrm{PGD}_{2}$ on Angptl4/FIAF gene expression were examined (Fig. 6 (a)). TNF- $\alpha$ had no effect on Angptl4/FIAF mRNA level,while IL-1 $\beta$ led to a modest (1.5-fold) increase in level at both doses. Treatment with IL-6, IL-10 and IL-18 led to very small (between 24 and $39 \%$ ) decreases in Angptl4/FIAF mRNA level which in some cases were statistically significant (Fig. 6 (a)).

Similar small changes in Angptl4/FIAF mRNA level were also observed when the adipocytes were treated with $\mathrm{PGE}_{2}$, $\mathrm{PGF}_{2 \alpha}$ and $\mathrm{PGI}_{2}$ (except with the high dose of $\mathrm{PGE}_{2}$, in which a 5-fold decrease in mRNA was observed). Treatment with $\mathrm{PGD}_{2}$, however, led to a major increase in Angptl4/ FIAF mRNA level, the increase being 7.2- and 8.5-fold at the low and high doses, respectively (Fig. 6 (a)). To investigate further the effect of $\mathrm{PGD}_{2}$ on Angptl4/FIAF expression,

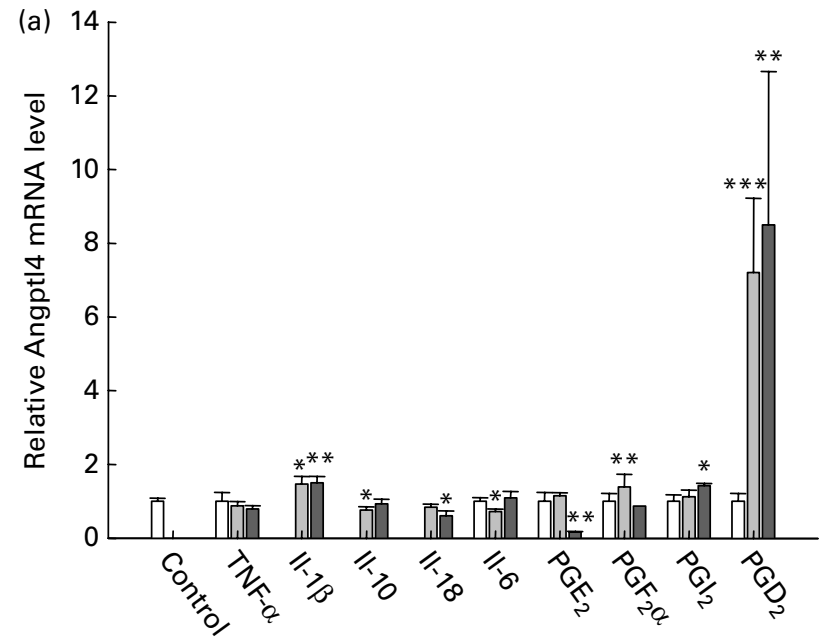

Inflammatory agent

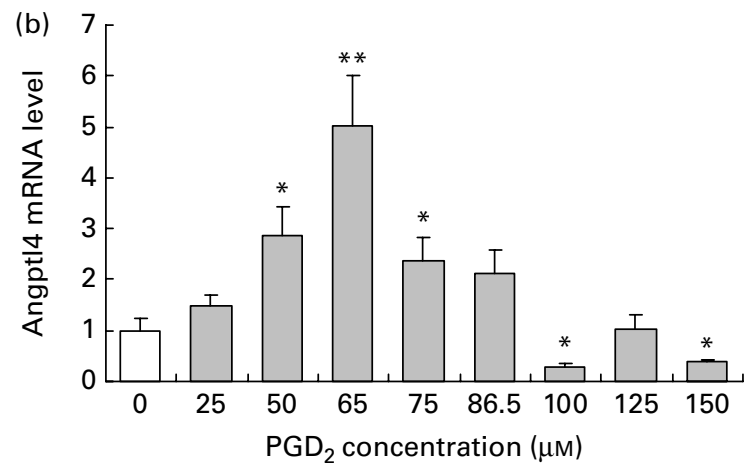

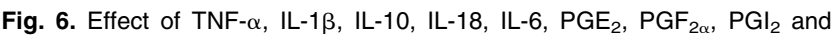
$\mathrm{PGD}_{2}$ on angiopoietin-like protein 4/fasting-induced adipose factor (Angpt/4/FIAF) mRNA levels. Cells were taken at day 12 after induction of differentiation and incubated for $24 \mathrm{~h}$ in media to which different amounts of each agent were added ( $\square$, low dose; $\square$, high dose). Control cells ( $\square$ ) received no addition. In (a), IL-6, low dose $1 \mathrm{ng} / \mathrm{ml}$, high dose $25 \mathrm{ng} / \mathrm{ml}$; IL$1 \beta$, low dose $5 \mathrm{ng} / \mathrm{ml}$, high dose $20 \mathrm{ng} / \mathrm{ml}$, IL-10, low dose $5 \mathrm{ng} / \mathrm{ml}$, high dose $20 \mathrm{ng} / \mathrm{ml} ; \mathrm{IL}-18$ low dose $100 \mathrm{ng} / \mathrm{ml}$, high dose $500 \mathrm{ng} / \mathrm{ml} ; \mathrm{PGE}_{2}, \mathrm{PGF}_{2 \alpha}$ and $\mathrm{PGD}_{2}$, low dose $50 \mu \mathrm{M}$, high dose $100 \mu \mathrm{M} ; \mathrm{PGI}_{2}$, low dose $50 \mu \mathrm{M}$, high dose $150 \mu \mathrm{M}$. In (b), the dose response to $\mathrm{PGD}_{2}$ was determined with the cells treated for $24 \mathrm{~h}$ in a medium supplemented with $0-150 \mu \mathrm{M}-\mathrm{PGD}_{2}$. Values for Angpt/4/FIAF mRNA levels, measured by real-time PCR, are expressed relative to their respective controls. Values are means with their standard errors depicted by vertical bars (A, $n 6$; $\mathrm{B}, n 4)$. Mean values were significantly different from those of the control group: ${ }^{\star} P<0.05$, ${ }^{\star \star} P<0.01,{ }^{\star \star \star} P<0.001$.

a dose response study was carried out using this PG (Fig. 6 (b)). Treatment with $\mathrm{PGD}_{2}$ led to a significant increase in Angptl4/FIAF mRNA at $50 \mu \mathrm{M}$ with a peak at $65 \mu \mathrm{M}$ after which the stimulatory effect of this PG fell.

Dependent upon conditions, $\mathrm{PGD}_{2}$ can spontaneously break down to $\mathrm{PGJ}_{2}$, which may then further convert to either $\Delta^{12}-\mathrm{PGJ}_{2}$ or 15 -deoxy $\mathrm{PGJ}_{2}^{(27,28)}$. Treatment with $\mathrm{PGJ}_{2}$ significantly increased Angpt14/FIAF mRNA level at a concentration of $10 \mu \mathrm{M}$ in a manner that was generally similar to $\mathrm{PGD}_{2}$, with the level peaking at $50 \mu \mathrm{M}$, while at higher doses the stimulatory effect was lost (results not shown).

\section{Discussion}

Studies on the physiological role of Angptl4/FIAF have suggested that this protein may be involved in both energy 
regulation, as a signal of fasting and as an inhibitor of LPL, and in angiogenesis. Angptl4/FIAF is reported to be highly expressed in WAT, brown adipose tissue and liver, with low expression in other tissues ${ }^{(5-7)}$. In the present study we found that expression of Angpt14/FIAF was evident in all tissues examined, with a strong PCR band detected in each of five different WAT depots, as well as in brown adipose tissue. Thus the Angptl4/FIAF gene is strongly expressed in all the main adipose tissues in mice. Quantitation by realtime PCR indicated that expression was generally higher in WAT than in the liver, and considerably greater than in skeletal muscle.

WAT is a heterogeneous tissue at the cellular level, with mature adipocytes constituting no more than $50 \%$ of the total cell content. Fractionation of WAT indicated that expression is essentially only in the mature adipocytes, there being little or no expression in the cells that constitute the stromal vascular component. Nevertheless, in the cell culture studies on 3T3-L1 adipocytes, some expression was evident prior to the induction of differentiation, albeit less than in the differentiated cells. This may reflect a difference between the clonal cell line and normal preadipocytes, or alternatively may indicate that any contribution from preadipocytes to Angptl4/FIAF mRNA in the stromal vascular fraction is diluted out by the other cellular components (e.g. endothelial cells, macrophages).

The pattern of Angptl4/FIAF expression in 3T3-L1 cells was similar to that observed by Mandard et al. ${ }^{(29)}$. We also found that there was a peak in expression at day 2 post-differentiation, and this may be attributable to a transient stimulation by the components present in the differentiation medium. Secretion of Angptl4/FIAF protein into the culture medium followed a similar overall pattern to that of gene expression, with the amount of protein released being higher post-differentiation and reaching a maximum at around day 14 .

Over-expression of Angtp14/FIAF has been found to inhibit LPL activity ${ }^{(11,14,30)}$. Since fasting leads to a fall in LPL activity in $\mathrm{WAT}^{(31)}$, and to a reported induction of Angtpl4/ FIAF expression in the tissue ${ }^{(6,7)}$, it has been proposed that a key physiological role of Angptl4/FIAF in vivo may be to regulate $\mathrm{LPL}^{(14)}$. However, in the present study no change in Angptl4/FIAF expression was observed in three different WAT depots of CD1 mice on fasting $(18 \mathrm{~h})$. The reason for this is unclear, but the fall in body weight together with a substantial decrease in leptin mRNA level in WAT (results not shown), indicate that the mice had responded substantially to fasting. Importantly, there was a strong increase in Angptl4/FIAF expression in both liver and skeletal muscle over the same time period, and a $2 \cdot 5$-fold increase in expression has been previously observed in WAT from $12 \mathrm{~h}$ fasted C57Bl Ks/J mice ${ }^{(7)}$.

The probable explanation for variations in the response to fasting is in differences between strains of mice. It has been observed that the increase in expression originally observed during fasting may not be observed in WAT from the FVB mice $\operatorname{strain}^{(13)}$. In the CD1 strain, Angplt4/FIAF expression has been shown to increase in the omental tissue after a $24 \mathrm{~h}$ fast $^{(24)}$. The very small size of the omental WAT in mice precluded its use in the present study, but the results suggest that there is no depot-specific regulation in CD1 mice. Overall, since fasting does not consistently induce Angplt4/FIAF expression in mice, the descriptor 'fasting-induced adipose factor' would seem inappropriate. Indeed, it could be argued that the impressive 20-fold increase in Angptl4/FIAF mRNA level in skeletal muscle with fasting suggests that the protein is in practice a 'fasting-induced muscle factor'.

The effect of fasting on Angptl4/FIAF expression in skeletal muscle is intriguing in view of the fact that LPL activity in muscle increases with fasting ${ }^{(32)}$. This raises questions on the putative role of Angplt4/FIAF as an inhibitor of LPL, but it should be noted that even after fasting the Angptl4/ FIAF mRNA level in skeletal muscle was still only half that of the subcutaneous WAT depot of fed mice. There was no detectable change in Angptl4/FIAF level in the plasma of the $\mathrm{CD} 1$ mice after a $18 \mathrm{~h}$ fast, suggesting that in this strain WAT may be the main source of the circulating protein. The size of the band detected in the plasma was $64 \mathrm{kDa}$, which is a higher molecular weight than that observed with the 3T3-L1 cells; this is probably due to differences in the extent of glycosylation of the protein.

Cell culture was used to investigate the regulation of Angpt14/FIAF expression in adipocytes. The range of agents examined reflect the proposed physiological roles of Angpt14/FIAF and include those involved in energy homeostasis, inflammation and angiogenesis. Treatment with agents such as insulin and leptin that are involved in energy homeostasis had little effect on Angptl4/FIAF expression, although incubation with the synthetic glucocorticoid, dexamethasone, led to a 2-fold reduction in the mRNA level. The glucocorticoids have anti-inflammatory actions, inhibiting the expression of TNF- $\alpha$ and other pro-inflammatory factors. Dexamethasone is also known to inhibit the activity of Cox-2, an enzyme involved in the synthesis of $\mathrm{PG}^{(33,34)}$.

During fasting, there is a marked increase in sympathetic activity to $\mathrm{WAT}^{(35)}$, which stimulates lipolysis and suppresses leptin expression ${ }^{(36,37)}$. Given the initial observations that Angpt14/FIAF expression in WAT was induced by fasting it was considered that the sympathetic system might play a key role in the regulation of Angptl4/FIAF synthesis. However, noradrenaline had no effect on Angptl4/FIAF mRNA level, and as discussed we were unable to observe a fastinginduced expression of Angptl4/FIAF in WAT.

Treatment of cells with the PPAR $\gamma$ agonist rosiglitazone led to a large stimulatory effect on Angptl4/FIAF expression, as in previous studies ${ }^{(6,7)}$. However, the stimulatory effect of rosiglitazone on gene expression was not mirrored in the level of Angptl4/FIAF secreted into the media, which remained unchanged. It is probable that the absence of an increase in secretion reflects the lag between alterations in gene expression and the translation and subsequent release of the mature protein product. This seems likely since increases in the level of Angptl4/FIAF in the medium have been observed following treatment of cells with PPAR agonists for 48 rather than $24 \mathrm{~h}^{(28)}$.

There was little effect on Angptl4/FIAF expression when 3T3-L1 adipocytes were treated with the pro-inflammatory cytokine TNF- $\alpha$, or with IL-1 $\beta$, IL-6, IL-10 and IL-18; several of these factors are expressed by WAT and their circulating level is increased in the mild inflammatory state of obesity $^{(3,4,38)}$. The only inflammation-related agents that affected Angpt14/FIAF expression were the inflammatory $\mathrm{PGD}_{2}$ and its derivative. There are limited reports on the effect of $\mathrm{PG}$ on WAT function, but it has recently been shown that $\mathrm{PGD}_{2}$ 
and the $\mathrm{J}_{2}$ series PG modulate the expression and secretion of IL-6, leptin, MCP-1 and nerve growth factor in 3T3-L1 adipocytes $^{(39,40)}$.

In conclusion, the present study demonstrates that the adipokine Angpt14/FIAF is strongly expressed in each of the main adipose tissue depots of mice. Since fasting for $18 \mathrm{~h}$ did not lead to any induction of Angptl4/FIAF expression in WAT, in contrast to the liver and skeletal muscle, it is unlikely that the protein can act as an adipose tissue-derived signal of overall nutrient status.

\section{Acknowledgements}

We are grateful to Mr Leif Hunter for his help and advice and to the Biotechnology and Biological Sciences Research Council (UK) for funding.

\section{References}

1. Zhang YY, Proenca R, Maffei M, Barone M, Leopold L \& Friedman JM (1994) Positional cloning of the mouse obese gene and its human homolog. Nature 372, 425-432.

2. Trayhurn P \& Beattie JH (2001) Physiological role of adipose tissue: white adipose tissue as an endocrine and secretory organ. Proc Nutr Soc 60, 329-339.

3. Rajala MW \& Scherer PE (2003) The adipocyte - at the crossroads of energy homeostasis, inflammation, and atherosclerosis. Endocrinology 144, 3765-3773.

4. Trayhurn P \& Wood IS (2004) Adipokines: inflammation and the pleiotropic role of white adipose tissue. Br J Nutr 92, 347-355.

5. Kim I, Kim HG, Kim H, Kim HH, Park SK, Uhm CS, Lee ZH \& Koh GY (2000) Hepatic expression, synthesis and secretion of a novel fibrinogen/angiopoietin-related protein that prevents endothelial-cell apoptosis. Biochem J 346, 603-610.

6. Kersten S, Mandard S, Tan NS, Escher P, Metzger D, Chambon P, Gonzalez FJ, Desvergne B \& Wahli W (2000) Characterization of the fasting-induced adipose factor FIAF, a novel peroxisome proliferator-activated receptor target gene. J Biol Chem 275, 28488-28493.

7. Yoon JC, Chickering TW, Rosen ED, Dussault B, Qin Y, Soukas A, Friedman JM, Holmes WE \& Spiegelman BM (2000) Peroxisome proliferator-activated receptor $\gamma$ target gene encoding a novel angiopoietin-related protein associated with adipose differentiation. Mol Cell Biol 20, 5343-5349.

8. Lee JH, Seo JM, Kim M \& Kim JC (2001) Cloning of cDNA for a novel fibrinogen/angiopoietin-related protein, FARP. Mol Cells 11, 100-104.

9. Conklin D, Gilbertson D, Taft DW, Maurer MF, Whitmore TE, Smith DL, Walker KM, Chen LH, Wattler S, Nehls M \& Lewis KB (1999) Identification of a mammalian angiopoietin-related protein expressed specifically in liver. Genomics 62, 477-482.

10. Ge H, Cha JY, Gopal H, Harp C, Yu X, Repa JJ \& Li C (2005) Differential regulation and properties of angiopoietin-like proteins 3 and 4. J Lipid Res 46, 1484-1490.

11. Yoshida K, Shimizugawa T, Ono M \& Furukawa H (2002) Angiopoietin-like protein 4 is a potent hyperlipidemia-inducing factor in mice and inhibitor of lipoprotein lipase. J Lipid Res $\mathbf{4 3}$, $1770-1772$.

12. Ge H, Yang G, Yu X, Pourbahrami T \& Li C (2004) Oligomerization state-dependent hyperlipidemic effect of angiopoietinlike protein 4. J Lipid Res 45, 2071-2079.

13. Xu A, Lam MC, Chan KW, Wang Y, Zhang J, Hoo RLC, Xu JY, Chen B, Chow W-S, Tso AWK \& Lam KSL (2005) Angiopoietin-like protein 4 decreases blood glucose and improves glucose tolerance but induces hyperlipidemia and hepatic steatosis in mice. Proc Natl Acad Sci U S A 102, 6086-6091.

14. Yu X, Burgess SC, Ge H, Wong KK, Nassem RH, Garry DJ, Sherry AD, Malloy CR, Berger JP \& Li C (2005) Inhibition of cardiac lipoprotein utilization by transgenic overexpression of Angptl4 in the heart. Proc Natl Acad Sci U S A 102, 1767-1772.

15. Le Jan S, Amy C, Cazes A, et al. (2003) Angiopoietin-like 4 is a proangiogenic factor produced during ischemia and in conventional renal cell carcinoma. Am J Pathol 162, 1521-1528.

16. Hermann LM, Pinkerton M, Jennings K, Yang L, Grom A, Sowders D, Kersten S, Witte DP, Hirsch R \& Thornton S (2005) Angiopoietin-like-4 is a potential angiogenic mediator in arthritis. Clin Immunol 115, 93-101.

17. Zhu H, Li J, Qin W, Yang Y, He X, Wan D \& Gu J (2002) Cloning of a novel gene, ANGPTL4 and the functional study in angiogenesis. Zhonghua Yi Xue Za Zhi 82, 94-99.

18. Ifon ET, Pang AL, Johnson W, Cashman K, Zimmerman S, Muralidhar S, Chan WY, Casey J \& Rosenthal LJ (2005) U94 alters FN1 and ANGPTL4 gene expression and inhibits tumorigenesis of prostate cancer cell line PC3. Cancer Cell Int 5, 19.

19. Belanger AJ, Lu H, Date T, Liu LX, Vincent KA, Akita GY, Cheng SH, Gregory RJ \& Jiang C (2002) Hypoxia up-regulates expression of peroxisome proliferator-activated receptor $\gamma$ angiopoietin-related gene (PGAR) in cardiomyocytes: role of hypoxia inducible factor $1 \alpha . \mathrm{J} \mathrm{Mol} \mathrm{Cell} \mathrm{Cardiol} \mathrm{34,} \mathrm{765-774.}$

20. Oliver P, Pico C \& Palou A (2001) Ontogenesis of leptin expression in different adipose tissue depots in the rat. Pflügers Arch Eur J Physiol 442, 383-390.

21. Oliver P, Pico C, Serra F \& Palou A (2003) Resistin expression in different adipose tissue depots during rat development. $\mathrm{Mol}$ Cell Biochem 252, 397-400.

22. Peeraully MR, Jenkins JR \& Trayhurn P (2004) NGF gene expression and secretion in white adipose tissue: regulation in 3T3-L1 adipocytes by hormones and inflammatory cytokines. Am J Physiol Endocrinol Metab 287, E331-E339.

23. Wiechelman KJ, Braun RD \& Fitzpatrick JD (1988) Investigation of the bicinchoninic acid protein assay: identification of the groups responsible for color formation. Anal Biochem 175, 231-237.

24. Backhed F, Ding H, Wang TT, Hooper LV, Koh GY, Nagy A, Semenkovich CF \& Gordon JI (2004) The gut microbiota as an environmental factor that regulates fat storage. Proc Natl Acad Sci U S A 101, 15718-15723.

25. Wiesner G, Morash BA, Ur E \& Wilkinson M (2004) Food restriction regulates adipose-specific cytokines in pituitary gland but not in hypothalamus. $J$ Endocrinol 180, R1-R6.

26. Wood IS, Hunter L \& Trayhurn P (2003) Expression of Class III facilitative glucose transporter genes (GLUT-10 and GLUT-12) in mouse and human adipose tissues. Biochem Biophys Res Commun 308, 43-49.

27. Fitzpatrick FA \& Wynalda MA (1983) Albumin-catalyzed metabolism of prostaglandin $\mathrm{D}_{2}$. Identification of products formed in vitro. J Biol Chem 258, 11713-11718.

28. Hirata Y, Hayashi H, Ito S, Kikawa Y, Ishibashi M, Sudo M, Miyazaki H, Fukushima M, Narumiya S \& Hayaishi O (1988) Occurrence of 9-deoxy- $\Delta 9, \Delta^{12-13,14}$-dihydroprostaglandin $\mathrm{D}_{2}$ in human urine. $J$ Biol Chem 263, 16619-16625.

29. Mandard S, Zandbergen F, Tan NS, Escher P, Patsouris D, Koenig W, Kleemann R, Bakker A, Veenman F, Wahli W, Muller M \& Kersten S (2004) The direct peroxisome proliferator-activated receptor target fasting-induced adipose factor (FIAF/PGAR/ANGPTL4) is present in blood plasma as a truncated protein that is increased by fenofibrate treatment. $J$ Biol Chem 279, 34411-34420.

30. Koster A, Chao YB, Mosior M, et al. (2005) Transgenic angiopoietin-like (Angptl)4 overexpression and targeted disruption of 
Angpt14 and Angpt13: regulation of triglyceride metabolism. Endocrinology 146, 4943-4950.

31. Bergo M, Olivecrona G \& Olivecrona T (1996) Diurnal rhythms and effects of fasting and refeeding on rat adipose tissue lipoprotein lipase. Am J Physiol Endocrinol Metab 34, E1092-E1097.

32. Kern PA (1997) Potential role of TNF $\alpha$ and lipoprotein lipase as candidate genes for obesity. J Nutr 127, 1917S-1922S.

33. Tordjman C, Coge F, Andre N, Rique H, Spedding M \& Bonnet $\mathrm{J}$ (1995) Characterisation of cyclooxygenase 1 and 2 expression in mouse resident peritoneal macrophages in vitro; interactions of non steroidal anti-inflammatory drugs with COX2. Biochim Biophys Acta 1256, 249-256.

34. Bell-Parikh LC, Ide T, Lawson JA, McNamara P, Reilly M \& FitzGerald GA (2003) Biosynthesis of 15-deoxy- $\Delta^{12,14}-\mathrm{PGJ}_{2}$ and the ligation of PPAR $\gamma . J$ Clin Invest 112, 945-955.

35. Migliorini RH, Garofalo MAR \& Kettelhut IC (1997) Increased sympathetic activity in rat white adipose tissue during prolonged fasting. Am J Physiol Regul Integr Comp Physiol 41, R656-R661.
36. Bartness TJ \& Bamshad M (1998) Innervation of mammalian white adipose tissue: implications for the regulation of total body fat. Am J Physiol Regul Integr Comp Physiol 44, R1399-R1411.

37. Trayhurn P, Duncan JS, Hoggard N \& Rayner DV (1998) Regulation of leptin production: a dominant role for the sympathetic nervous system? Proc Nutr Soc 57, 413-419.

38. Trayhurn P \& Wood IS (2005) Signalling role of adipose tissue: adipokines and inflammation in obesity. Biochem Soc Trans 33, 1078-1081.

39. Bullo M, Peeraully MR \& Trayhurn P (2005) Stimulation of NGF expression and secretion in 3T3-L1 adipocytes by prostaglandins $\mathrm{PGD}_{2}, \mathrm{PGJ}_{2}$ and $\Delta^{12}-\mathrm{PGJ}_{2}$. Am J Physiol Endocrinol Metab 289, E62-E67.

40. Peeraully MR, Sievert H, Bullo M, Wang B \& Trayhurn P (2006) Prostaglandin $\mathrm{D}_{2}$ and $\mathrm{J}_{2}$-series $\left(\mathrm{PGJ}_{2}, \Delta^{12}-\mathrm{PGJ}_{2}\right)$ prostaglandins stimulate IL-6 and MCP-1, but inhibit leptin, expression and secretion by 3T3-L1 adipocytes. Pflügers Archiv Eur J Physiol 453, 177-187. 